\title{
Polonistyczny regres, czyli o projektowanej dydaktyce polonistycznej
}

\author{
Polish-studies regression, \\ or on designing Polish language didactics
}

\begin{abstract}
Summary: The author undertakes the topic of the Polish language education undergoing constant reform. She refers to the fact that the reformers disregard established didactic conclusions and take into account neither the students' needs nor the subjectivity of both young people and teachers. She indicates restrictions imposed on the spheres of school leeway and, at the same time, the expansion of the prescribed duties. Additionally, she points to the school curriculum overload. While underscoring the flaws of the literary mandatory readings' chronological ordering, she elucidates that the contemporary perspective, which have been introduced in teaching, is largely ostensible. What she proves is that editors of new Polish language school books simply multiple requirements towards teenage students and their humanist formation. She denies the purposefulness of teaching multitude of terms to students, and reminds us that such a rote learning trains memory but does not teach one how to think. She describes the petrification of knowledge of language and omission of communicative learning, which both stem from the core curriculum and the conservatism of handbooks. She is convinced that what is genuinely important may transpire at school outside the core curriculum and the scope of school books.
\end{abstract}

Keywords: the core curriculum, Polish language didactic, history of literature taught at school, handbooks/student's books, contemporary contexts, grammar, language communication

Szkoła w Polsce jest nieustannie reformowana. I nie byłoby w tym nic złego, gdyby zmiany powiązane były z wyciąganiem wniosków zarówno z walorów, jak i ograniczeń wcześniejszych rozwiązań. Niestety, kolejni reformatorzy zapominają o minionych dokonaniach. Pomijają ustalenia dydaktyków i rozmijają się z oczekiwaniami uczniów. Postanowienia decydentów coraz bardziej ograniczają też swobodę nauczycieli. 
Obowiązująca obecnie Podstawa programowa ksztatcenia ogólnego dla czteroletniego liceum ogólnokształcącego i pięcioletniego technikum z 2018 roku przywraca jako obowiązkowy w zakresie kształcenia polonistycznego chronologiczny układ treści nauczania i zawiera oczekiwanie wprowadzania wynikających z niego licznych zagadnień kulturowych. Z jednej strony wymusza poznawanie tekstów zgodnie z porządkiem ich powstawania, $\mathrm{z}$ drugiej - zaleca równoczesne włączanie rozmaitych kontekstów lekturowych: historycznoliterackich, historycznych, politycznych, kulturowych, filozoficznych, biograficznych, mitologicznych, biblijnych, egzystencjalnych ${ }^{1}$. W części rozporządzenia zatytułowanej Warunki i sposób realizacji czytamy ponadto:

[...] nauczanie języka polskiego na tym etapie edukacyjnym nie może sprowadzać się jedynie do uczenia historii literatury, może to bowiem prowadzić do encyklopedyzmu czy mnożenia faktów. Chronologia ma stanowić punkt odniesienia, umożliwić rozwijanie świadomości historycznoliterackiej uczniów, co powinno dokonywać się poprzez porównywanie zjawisk literackich w czasie. Należy przyjąć perspektywę współczesną do wprowadzania do tradycji.

PP 2018, s. 38

To słuszne skądinąd założenie nie jest łatwe do zrealizowania i paradoksalnie - o czym dalej — formułuje wobec szkolnej polonistyki kolejne spore wymagania. Stawia przed nauczycielami dodatkowe warunki, które muszą wziąć pod uwagę w trakcie pracy z licealistami i uczniami techników.

Zadziwia jednak, że niektórzy twórcy nowych podręczników jeszcze bardziej, niż wynikałoby to z podstawy programowej, mnożą ponad wszelkie miary oczekiwania wobec nastolatków i ich humanistycznego kształcenia. Szczególnie mocno odczuć to mogą młodzi ludzie przechodzący z gimnazjum czy szkoły podstawowej na kolejny poziom edukacji polonistycznej. Mają oni zazwyczaj poznawać: starożytność, średniowiecze, renesans, oświecenie. Uczniom klas I liceum kłopoty sprawiają tymczasem nie tylko teksty pochodzące z tych minionych epok. Równie niełatwe mogą się okazać także wspomniane wcześniej współczesne konteksty. Wymagają one przecież sporej świadomości kulturowej, której piętnastolatkowie jeszcze nie mają.

${ }^{1}$ Zob. Podstawa programowa kształcenia ogólnego dla czteroletniego liceum ogólnokształcącego i pięcioletniego technikum. Załącznik nr 1 do rozporządzenia Ministra Edukacji Narodowej z dnia 30 stycznia 2018, s. 27. Dalej odwołania do tego aktu prawnego zaznaczać będę w nawiasie jako PP 2018, podając odpowiednią stronę. 


\section{Nowy podręcznik i uwagi z przeszłości}

Na problemy związane z nauką lektury projektowaną w szkolnych podręcznikach zwracano uwagę od dawna. Warto przypomnieć już chyba nieco zapomnianą autoanalizę dokonaną przez Bożenę Chrząstowską. W czasie wizyty w szkole poprosiła uczniów o ocenę książki, z której licealiści na co dzień korzystali, a której ta poznańska badaczka była współautorką². Ponieważ działo się to na początku lat dziewięćdziesiątych XX wieku, kiedy publikowano szare, pozbawione koloru i drukowane na kiepskiej jakości papierze książki, młodzi ludzie negowali jakość edytorską podręcznika. Zwracali jednak uwagę przede wszystkim, co i w kontekście współczesnym warto mocno podkreślić — na niezrozumiałość podręcznikowej narracji. Starając się wyjaśnić powody uczniowskich trudności, Chrząstowska przywoływała analizy językoznawcze skupiające się na składni, leksyce, stylu pisania książek szkolnych ${ }^{3}$. Zauważała również:

Niekomunikatywność podręcznika nie wywodzi się jednak tylko z samego języka. Mój wstęp został oceniony przez młodych odbiorców bardzo wysoko, moje wprowadzenie do epoki starożytności jest dla nich niezrozumiałe. Dlaczego? — przecież pisałam to tak samo prostym językiem, co można sprawdzić. Sprawdzić można jednak i to, że pisałam fragmenty wykładu jak inteligent do inteligenta, który wszystko wie i niczego mu nie trzeba wyjaśniać. Np. — zna i rozumie pojęcie kultury, doskonale pojmuje, co składa się na pojęcie kultury europejskiej, bez trudu lokalizuje — w czasie i przestrzeni — źródła tej kultury.

I w aktualnych podręcznikach zamieszczane są wprowadzenia czy inne fragmenty rozpoczynające kolejne rozdziały, gdzie wymienia się w nadmiarze nazwiska twórców, których tekstów uczniowie nie będą czytać. Równie hojnie przywołuje się odległe dla pierwszoklasistów zjawiska. W jednym z takich wstępów na jednej stronie naliczyłam dwadzieścia nazwisk oraz kilkanaście terminów z zakresu historii literatury i kultury starożytnej. I przywołani twórcy, i historycznoliterackie czy kulturowe problemy, o których się mówi w tych

2 Zob. M. Adamczyk, B. Chrząstowska, J.T. Pokrzywniak: Starożytność - oświecenie. Podręcznik literatury dla klasy pierwszej. Warszawa 1987.

${ }^{3}$ Zob. S. Gajda, A. Słodzińska: Struktura językowa podręcznika. W: Podręczniki literatury w szkole średniej. Wczoraj - dziśs - jutro. Red. B. Chrząs tow ska. Poznań 1981, s. 117135. Por. K. Gąsiorek: Komunikatywność (czytelność) podręczników literatury a język uczniów w szkole średniej. W: Podręczniki literatury w szkole średniej. Wczoraj — dziś — jutro..., s. $137-145$.

${ }^{4}$ B. Chrząstowska: Cegła. „Polonistyka” 1992, nr 1, s. 56. 
podręcznikowych cząstkach, są licealistom z reguły nieznane. Mogą je zapamiętać. Powątpiewać jednak można, co z takich „wprowadzeń” mają zrozumieć i jak spożytkować w dalszej pracy tak „,naszpikowany” nazwiskami i terminami podręcznikowy tekst ${ }^{5}$.

To, co dzięki rozmowom z uczniami dostrzegła we własnej wypowiedzi i z dezaprobatą oceniła Bożena Chrząstowska — wybitna znawczyni dydaktyki polonistycznej (tę opinię dokumentuje sygnalizowany wcześniej jej autokrytycyzm...) - dotyczy nie tylko wprowadzania do epok dawnych. Analogiczne zjawisko towarzyszy także traktowanym kontekstowo nawiązaniom do szeroko rozumianej współczesności. Zważmy bowiem, co tym ostatnim mianem określić mogą obecni piętnasto-, szesnastolatkowie? Czy istotnie potraktują tak odwołania do twórczości Edwarda Stachury i Haliny Poświatowskiej? Co wiedzą o stalinizmie i pokoleniu „Współczesności”? Jaką mają świadomość tego, czym charakteryzowała się twórczość doby PRL-u? Jak mogą rozumieć sugestię o osobnym miejscu wspomnianych twórców na literackiej, a nawet szerzej: kulturowej mapie tego okresu? Młodzi użytkownicy wybranego tu przykładowo nowego podręcznika zgodnie z zawartymi w nim sugestiami mają przecież też odwołać się na przykład do plakatu anonsującego nieznany im film z tego okresu. Co zatem mówi obecnym nastolatkom sugestia o umieszczeniu akcji dzieła filmowego w realiach lat siedemdziesiątych XX wieku? Znają je? Rozumieją rzeczywistość biograficznie odległą nawet wielu osobom z pokolenia ich rodziców? Jakie trzeba by uwzględnić informacje, aby nie „zaciemniać obrazu” tego, z czego wynika wartość dzieła filmowego, a uczniowie mogli nie tylko przyjąć te kwestie do wiadomości, ale i dostrzec to, dlaczego upływ czasu nie umniejszył znaczenia filmu? Można — oczywiście - uznać, że zadania tego typu przeznaczone są tylko dla humanistów, uczniów o ponadprzeciętnej świadomości literacko-kulturowej, realizujących kształcenie polonistyczne w zakresie rozszerzonym. Zaraz jednak musi nasunąć się pytanie: czego zatem oczekuje się od licealistów w ramach zakresu podstawowego? Wymóg wpisany w podstawę programową dotyczący patrzenia na przeszłość z perspektywy współczesności ich także dotyczy. Tymczasem w ramach powtórzenia i sprawdzenia wiadomości nabytych przez uczniów w trakcie pracy z materiałami pomieszczonymi w całym dziale podręcznika nie przewidziano dla tej grupy licealistów ani jednego zadania, dzięki któremu mogliby pokazać, że dawna kultura łączy się z ich obecnymi doświadczeniami, że to, co minione, może odkrywać sens ich włas-

${ }^{5}$ W innym szkicu Jak uczyć rozumienia historyczności w nowym liceum także już przed laty Chrząstowska dowodziła: „Czas, który nauczyciel zużywa na przekazywanie wiedzy, a uczeń na jej reprodukcję, jest czasem źle wykorzystanym, by nie rzec - czasem straconym. Właśnie dlatego nauczanie szkolnej historii literatury jest nieskuteczne". Zob. B. Chrząstowska: Przedmiot, podmiot i proces. Szkice z metodyki ksztatcenia polonistycznego. Wybór i oprac. M. Kwiatkowska-Ratajczak, W. Wantuch. Poznań 2009, s. 167. 
nego tu i teraz. Pytania i polecenia wymagają odtworzenia wiedzy o minionych zjawiskach historycznoliterackich ${ }^{6}$.

Podobna autoanaliza, jak ta dokonana przez Chrząstowską w relacji do jej współautorskiego podręcznika z lat dziewięćdziesiątych XX wieku, z pewnością przydałaby się i twórcom aktualnych szkolnych książek. Dobrze byłoby ją przeprowadzić nie tylko przy biurku, lecz także obserwując zachowania rzeczywistych odbiorców - uczniów. Trzeba przy tym pamiętać, że kształcenie literackie i kulturowe ma przecież — zgodnie z oczekiwaniami wynikającymi z podstawy programowej - akcentować ich egzystencjalne doświadczanie siebie, innych, świata..., ma inspirować do zadawania pytań dziełu, pytań warunkowanych kontekstem osobistym i kulturowym..., a preferowanym kierunkiem lekcyjnego działania ma być rozwijanie refleksyjności młodych ludzi (zob. PP 2018, s. 38).

Jasną ocenę własnej propozycji zawarła Bożena Chrząstowska (współtwórczyni do dziś wspominanej z nostalgią przez wielu obecnych polonistów szkolnej książki, ale przecież zarazem autorka całego jej metodycznego zamysłu) już w tytule autorecenzji: Cegła. Krytycznie bowiem odniosła się do jakości edytorskiej i objętości tego rewolucyjnego w owych czasach podręcznika, który w zależności od wydania (było ich kilkanaście!) liczył czterysta pięćdziesiąt pięćset stron. Dzisiejsi uczniowie korzystają z książek kolorowych, ładnie wydanych, ale mających niekiedy blisko siedemset stron... i nie tylko ta ich ogromna objętość może dydaktyka niepokoić. Zastanawia także sposób wprowadzania wielu ilustracji. W podręczniku są one przecież ważnym elementem procesu kształcenia i to koncepcja dydaktyczna — o czym także przed wieloma już laty przekonywał inny znamienity dydaktyk Zenon Uryga — musi być nadrzędna wobec pozostałych zadań szkolnej książki. Ujawniają ją zarówno warstwa merytoryczna, jak i sposób strukturyzowania treści, formułowania pytań, proponowane ćwiczenia i projekty, a także funkcjonalność materiału ilustracyjnego 7 . Ikonografia powiązana $\mathrm{z}$ tematem może go dokumentować, może być traktowana kontekstowo, może też służyć nauce czytania obrazu. Każdy z tych sposobów w zależności od konkretnej sytuacji bywa z pewnością uzasadniony

${ }^{6}$ Wszystkie przykłady zaczerpnęłam z jednego spośród obowiązujących obecnie podręczników. Celowo nie podaję w tym miejscu odpowiedniego przypisu. Nie jest bowiem moim zamierzeniem opiniowanie konkretnej szkolnej książki, ale zwrócenie uwagi na poważniejszy, wykraczający poza to exemplum, szerszy/głębszy problem dydaktyczny.

${ }^{7}$ O roli podręcznika szkolnego zob. Z. Uryga: Podręcznik jako narzędzie kształcenia literackiego w szkole średniej. W: Podręczniki literatury w szkole średniej..., s. 13-34. Por. Z. Uryga: Kryteria oceny podręczników szkolnych do literatury i historii. W: Prace Komisji do Oceny Podręczników Szkolnych. T. 1. Red. A. Kastory, G. Chomicki. Kraków 2002, s. 13-21. O wielorakiej roli dydaktycznej szkolnych książek polonistycznych mówił też Zenon Uryga — jeden z najlepszych znawców tego tematu - na IV Kongresie Dydaktyki Polonistycznej w Poznaniu (20-23 listopada 2019). 
metodycznie. Uwagę zwracają jednak i takie rozwiązania podręcznikowe, kiedy fotos czy rysunek nie tylko nie wymagają, a nawet nie zachęcają do pogłębienia obserwacji; ich zadaniem jest bowiem raczej jedynie ,upiększenie” książki, na co zwracał uwagę - przywołam kolejnego znawcę polonistyki szkolnej — Stanisław Bortnowski ${ }^{8}$. Brak sugestii sposobów wykorzystania ilustracji bywa niekiedy celowy, innym razem wywołuje zdziwienie, ale dydaktyczne obawy wynikają jednak z czegoś innego. Trudno bowiem zrozumieć, dlaczego na przykład niszczy się zamysł artysty, pozbawiając stworzony przez niego wizerunek elementu istotnego kulturowo i możliwego do — właśnie metodycznego — spożytkowania. Tak jest, kiedy na przykład na reprodukowanej fotografii powszechnie znanej rzeźby Michała Anioła, przedstawiającej Mojżesza, w szkolnym podręczniku ucina się ten fragment głowy, który Buonarroti opatrzył charakterystycznymi rogami...9. Pomija się tym samym możliwość pokazania, że ten dawny wizerunek obrazuje jedną z najbardziej znanych pomyłek stanowiących równocześnie źródło częstego motywu na rycinach, obrazach czy posągach. W odniesieniu do wyrzeźbionej przez Michała Anioła monumentalnej postaci przywódcy Izraelczyków w każdym kompendium historii sztuki mowa jest o omyłce w tłumaczeniu Biblii, jaką popełnił Święty Hieronim. Wskazuje się przy tym, że Hieronim był nie tylko świętym, ale i wybitnym uczonym, a jednak popełnił błąd... Tłumacząc fragment Pisma Świętego, w którym mowa jest o powrocie Mojżesza z góry Synaj, hebrajskie słowo qaron (,promieniować”) oddał jako cornatus (,rogaty”), powodując, że ten sam defekt pojawił się i w innych tłumaczeniach, dla których przekład Świętego Hieronima stał się podstawą (także na przykład w przekładzie Jakuba Wujka). Dało to tym samym początek motywu rogatego Mojżesza. Dlaczego nie wykorzystać tej popularnej historii jako motywacji/zachęcenia uczniów do poznawania minionych dziejów Wulgaty i jej wpływu na kulturę? Rogi z rzeźby Michała Anioła mogą też być inspiracją dla licealistów nie tylko do poszukiwań podobnych wizerunków Mojżesza, ale i porównania późniejszych przekładów, których przywołanie pozwala na naturalną integrację kształcenia kulturowo-literackiego i językowego.

${ }^{8}$ O różnych możliwościach powiązania słowa z obrazem w polonistycznych podręcznikach pisał między innymi S. Bortnow ski: Modele prezentacji malarstwa, grafiki i rysunku w podręcznikach gimnazjalnych. W: Podręcznik jako narzędzie ksztatcenia polonistycznego w gimnazjum. Red. H. Kosętka, Z. Uryga. Kraków 2002, s. 124-132. Sporo uwagi temu zagadnieniu poświęcił też P. Kołodziej: Czas na obraz. Dzieło malarskie jako tekst $i$ kontekst w szkolnym ksztatceniu humanistycznym (1880-1999). Kraków 2013, s. 223-250.

${ }^{9}$ Nie sposób uznać, że sytuacja taka w przypadku dużego przecież nakładu podręcznika jest wynikiem braku profesjonalizmu, by nie rzec niefrasobliwości drukarni. 


\section{Terminy — pamięć czy myślenie?}

Efektywne korzystanie ze szkolnej książki jest też złudne, kiedy wprowadza się $\mathrm{w}$ niej $\mathrm{w}$ nadmiarze profesjonalne terminy. W analizowanym przeze mnie polonistycznym podręczniku znaleźć można przykład, gdzie w efekcie omówienia kilkunastu zagadnień literackich i językowych nastolatek ma przyswoić blisko trzydzieści pojęć, a we wcześniejszej autorskiej narracji dotyczącej tych samych tematów użytych zostało zdecydowanie ponad czterdzieści dodatkowych terminów, z których nie wszystkie wymienione są w i tak przeładowanej podstawie programowej z 2018 roku. Już w pierwszym semestrze w I klasie liceum nastolatek ma wiedzieć, czym są między innymi: sacrum i profanum, vanitas, papirologia, biblistyka, rozpoznać 5 odmian psalmów (błagalne - lamentacyjne, pochwalne, dziękczynne, ufności, madrościowe - dydaktyczne), rozumieć wizję prorocza, rozróżniać element znaczacy - znaczony oraz dwanaście rodzajów zdań złożonych, rozróżniać pauzę wersyfikacyjna, wiersz metryczny $i$ stychiczny, paralelizm składniowy i znaczeniowy, umieć dostrzec segmentację i rytmizację tekstu, anaforę spójnikowa i parabolę, ale też znać entymemat czy hymn ambrozjański... Zawarte w książce sprawdzające polecenia typu: wymień i krótko omów, objaśnij pojęcie ewidentnie wskazują też na oczekiwanie od ucznia przypomnienia/odtworzenia twardej wiedzy. Z indeksu książki wynika zaś, że wśród definiowanych w ciągu mniej więcej pół roku pojęć pojawia się ponad dwieście osiemdziesiąt różnego rodzaju terminów z zakresu poetyki, teorii i historii literatury czy wiedzy o języku. Nie wszystkie zaś — powtórzę — używane w narracji podręcznikowej kategorie są wymienione w indeksie ${ }^{10}$.

Komentując i takie zjawisko, muszę ponownie odwołać się do innych, dawnych ustaleń Bożeny Chrząstowskiej. Ta — chyba najbardziej znana polska badaczka zajmująca się problematyką związaną z wprowadzaniem pojęć z poetyki i teorii literatury do edukacji polonistycznej ${ }^{11}$ — wielokrotnie krytycznie odnosiła się do odtwórczego traktowania terminologii. Terminów oraz ich definicji — jak przekonywała — łatwo nauczyć i zweryfikować ich znajomość.

${ }^{10}$ Zarówno wcześniejsze odwołania do autoanalizy Chrząstowskiej, jak i kolejne nawiązania do ustaleń Zenona Urygi, Stanisława Bortnowskiego nie mają na celu jedynie oceniania rozwiązań metodycznych zawartych w konkretnej licealnej książce, ale wspieranie dydaktycznej egzemplifikacji problemu. To jest też powód — podkreślę raz jeszcze — rezygnacji z przypisu lokalizującego wybrane podręcznikowe przykłady. Dodać warto, że analogiczne zjawisko nadmiaru terminologicznego dotyczy nie tylko książek polonistycznych, ale i podręczników do innych szkolnych przedmiotów.

${ }^{11}$ Zajmowała się tymi zagadnieniami już od lat siedemdziesiątych XX wieku. Zob. B. Chrząs tow ska: Teoria literatury w szkole. Z badań nad recepcją liryki. Wrocław-Warszawa-Kraków—Gdańsk 1979; Ea de m: Lektura i poetyka. Zarys problematyki kształtowania pojęć literackich w szkole podstawowej. Warszawa 1987. 
Sprawdzamy wówczas jednak tylko uczniowską umiejętność magazynowania w umyśle kolejnych danych. Takie bowiem dedukcyjne nauczanie polega na transmisji wiedzy, na przekazywaniu faktów odkrytych przez naukę, wykorzystuje pamięć ucznia i do niej się odwołuje. Ukryte za terminami pojęcia mają zaś służyć lekturze. Ich poznawanie to z kolei długi, podzielony na etapy proces kształcenia zachodzący podczas czytania, omawiania i analizy tekstu. Przypomnijmy: wymaga on działań propedeutycznych, kiedy się uruchamia raczej lekturową uważność, ćwiczy dostrzeganie zjawiska, obserwuje pojęcie i nie wprowadza terminu; etap właściwy z kolei ukierunkowany jest na kojarzenie desygnatu z konkretnym zjawiskiem/rzeczą, ale i związany z porównywaniem, abstrahowaniem od elementów niekoniecznych, uogólnianiem cech i wprowadzaniem terminu, czyli — inaczej mówiąc - nazwy pojęcia; etap wdrożeniowy następuje dopiero wówczas, gdy w procesie lektury świadomie uwzględnia się pojęcie i dostrzega jego funkcję, a termin ekonomizuje porozumiewanie się $\mathrm{z}$ nauczycielem, choć przecież nie on jest tu celem lekcyjnych obserwacji ${ }^{12}$.

I tu znowu można odwołać się do deklaracji zawartych w obowiązującej podstawie programowej dla szkół ponadpodstawowych. W preambule do niej czytamy, że poznawana przez ucznia wiedza ma być podwaliną pod kształtowanie umiejętności, a te z kolei mają inspirować do formułowania samodzielnych sądów oraz ich uzasadniania w procesie dialogu we wspólnocie dociekającej. Za najważniejsze umiejętności twórcy dokumentu uznają myślenie, rozumienie sensów i znaczeń symbolicznych, kreatywne rozwiązywanie problemów, samodzielne docieranie do informacji i formułowanie sądów, współpracę w grupie (zob. PP 2018, s. 1-2). Takie sprawności wykształcić można, stosując czasochłonną metodę indukcyjną, polegającą na wspólnej z uczniami obserwacji istotnych cech konkretnego pojęcia, pogłębieniu analizy, pobudzaniu uczniów do spostrzegania i wnioskowania o istocie poznawanej kategorii złożonej $\mathrm{z}$ wielu desygnatów. Założeniem działania indukcyjnego jest bowiem właśnie uaktywnianie myślenia jako najważniejszej umiejętności pozwalającej na analizowanie zjawisk, wyciąganie wniosków i dociekanie sensu, a dzięki temu na aktywne uczestniczenie w świecie. Pozwala to - co ważne — integrować proces wprowadzania pojęć z rozwijaniem umiejętności analizy i interpretacji tekstów kultury oraz z formacyjną funkcją edukacji polonistycznej. Jak słusznie też zauważył nie tak dawno Dariusz Szczukowski, powołując się między innymi na prace Richarda Rorty'ego, Jacques'a Derridy, Michała P. Markowskiego, celem uczenia sztuki interpretacji nie jest wyłącznie jej profesjonalizacja i wykształcenie rzeszy literaturoznawców:

${ }_{12}$ Zob. B. Chrząstowska, A. Wójtowicz-Stefańska: Kształtowanie pojęć na lekcjach języka polskiego. W: Innowacje i metody. W kręgu teorii i praktyki. Podręcznik akademicki dydaktyki kształcenia polonistycznego. Red. M. Kwiatkowska-Ratajczak. Poznań 2011, s. $278-279$. 
Należy jednak pamiętać — pisał Szczukowski — że sprowadzenie interpretacji tylko i wyłącznie do kolejnej umiejętności pozwalającej oswoić i ,opanować" dzieło w ramach wypracowanej siatki pojęć może prowadzić do instrumentalizacji literatury ${ }^{13}$.

Przypomnijmy: to również Bożena Chrząstowska przestrzegała już przed laty przed fetyszem terminu i grzechotką teoretyczną w edukacji szkolnej ${ }^{14}$. Także w przywoływanej wcześniej autoanalizie podręcznika z lat dziewięćdziesiątych XX wieku zwracała uwagę i na inne uwarunkowania kształcenia na poziomie licealnym. Udokumentowała mocny rozziew między projekcją wirtualnego odbiorcy podręcznika a jego rzeczywistym użytkownikiem. Już wtedy też pisała:

[...] trzeba zasadniczo zmienić terapię, dokonać przewartościowań w celach nauczania: nie historia literatury czy teoretyczna wiedza o dziele literackim jest najważniejsza - cele poznawcze trzeba przesunąć na plan dalszy. „Najpierw język!” i sprawność w jego użyciu — chciałoby się powiedzieć, trawestując tytuł i pomysł teleologiczny Marii Jędrychowskiej. Ta obserwacja wyniesiona ze spotkania [z młodzieżą - M.K.R.] powinna także znaleźć wyraz w zmienionym kształcie podręcznika; nauczanie licealne musi w znacznie większym stopniu integrować starania o kompetencje tak odbiorcze, jak i nadawcze uczniów ${ }^{15}$.

\section{Komunikacja czy unieruchomiona wiedza?}

Dla kształcenia kulturowo-literackiego nie pozostaje obojętne, jak projektowane i realizowane jest kształcenie językowe. To wniosek oczywisty także

${ }^{13}$ D. Szczukowski: Nauczanie literatury jako wyzwa(la)nie i wyznanie. W: Polonistyka dziś - ksztatcenie dla jutra. T. 1. Red. K. Biedrzycki, W. Bobiński, A. Janus-Sitarz, R. Przybylska. Kraków 2014, s. 415-416.

${ }^{14} \mathrm{O}$ niebezpieczeństwie fetyszyzacji terminu pisała już w Teorii literatury w szkole (zob. s. 150-156) na przełomie lat siedemdziesiątych i osiemdziesiątych XX wieku i przypominała w podręczniku akademickim Innowacje $i$ metody... w roku 2011 (por. s. 272-273). Krytycznie na ten temat wypowiadała się też Zofia Agnieszka Kłakówna, wskazując zarazem, że propozycje Bożeny Chrząstowskiej nie zostały przełożone na rozwiązania podręcznikowe i poradnikowe. Zob. Z.A. Kłakówna: Przymus $i$ wolność. Projektowanie procesu ksztatcenia kulturowej kompetencji. Kraków 2003, s. 180-201.

15 B. Chrząstowska: Cegła..., s. 57. Podkr. - M.K.R. 
w kontekście wielu prac dydaktycznych z przełomu XX i XXI wieku ${ }^{16}$. Lingwiści wskazywali znaczenie kognitywistyki, zwracali uwagę na rolę nawiązań do kwestii komunikacyjnych i swoistego „,zwrotu kulturowego”, koniecznego także w obrębie metodyki kształcenia językowego. Już w 2004 roku na Zjeździe Polonistów w Krakowie Stanisław Gajda wiele mówił o konieczności przekraczania granic dyscyplin i potrzebie reorganizacji sposobu poznawania. Obserwując poszerzenie przedmiotu badań językoznawczych, podkreślał znaczenie analiz użycia języka przez ,użytkowników zanurzonych w konkretnych sytuacjach porozumiewania i w kontekście społeczno-kulturowym oraz tworzących dyskurs (por. traktowanie języka jako zbioru dyskursów)"'17.

Lingwodydaktycy od lat dziewięćdziesiątych XX wieku postulowali odchodzenie od traktowania języka wyłącznie jako systemu, tradycyjnego poznawania hierarchicznego układu jego kolejnych poziomów (od fonetyki do składni) i przechodzenie ku modelowi komunikacyjnemu ${ }^{18}$. Był on wpisany i w podstawę programową z roku 1998/1999, i w nowatorskie podręczniki z tamtego okresu, na przykład z cyklu To lubię! $!^{19}$ oraz towarzyszące im książki dotyczące sztuki pisania ${ }^{20}$. Mocno eksponowana była retoryka, a twórcy pierwszej podstawy programowej uznali ją za ,główny kontekst kształtowania sprawności językowych" ${ }^{21}$. Jasno jednak ostrzegali przed uczeniem definicji i terminów, a przekonywali o potrzebie uzmysławiania uczniom posiadanej przez nich wiedzy o aktach mowy, umiejętności formułowania wypowiedzi w konkretnych przypadkach/okolicznościach komunikacyjnych, w zależności od tego, kto, do kogo, w jakiej sytuacji, w jakim celu, z jakim skutkiem mówi. Tymczasem jak trafnie zauważył Jerzy Kaniewski — w najnowszej podstawie programowej i dla szkół podstawowych (z roku 2017), i ponadpodstawowych (dokument

${ }^{16}$ Obszerną dokumentację tej tezy znaleźć można między innymi w książce J. Nocoń: Lingwodydaktyka na progu XXI wieku. Konteksty — koncepcje — dylematy. Opole 2018.

17 S. Gajda: Język - językoznawstwo - polonistyka. W: Polonistyka w przebudowie. T. 1. Red. M. Czermińska i inni. Kraków 2005, s. 33.

18 Szerzej na ten temat zob. np. K. Koc: Od gramatyki opisowej do gramatyki komunikacyjnej. „Polonistyka” 2009, nr 4.

19 Taki zamysł kształcenia językowego organizował cały cykl edukacyjny zaprojektowany w ramach tej serii książek. Był obecny zarówno w podręcznikach dla szkoły podstawowej, jak i gimnazjum oraz liceum.

${ }^{20}$ Zob. Z.A. Kłakówna: Sztuka pisania. Ćwiczenia redakcyjne dla klas IV-VI. Metodyczny podręcznik nauczyciela. Warszawa 1993. Por. Z.A. Kłakówna, I. Steczko, K. Wiatr: Sztuka pisania. Klasy 1-3 gimnazjum. Książka nauczyciela. Kraków 2003.

${ }^{21}$ Zob. T. Zgółka: Nauczanie o języku (na trzech etapach edukacji szkolnej). „Polonistyka” 1999, nr 7, s. 405. Tam też Tadeusz Zgółka, współtwórca pierwszej podstawy programowej, pisze o innych aspektach kształcenia językowego, między innymi o związku z nauczaniem języków obcych, etyce mówienia, odmianach języka i znaczeniu przekładania języka z jednej odmiany na inną, czy o historii języka traktowanej jako składnik dziejów kultury. 
z 2018 roku) „komunikacja językowa stała się na obu poziomach nauczania po prostu jednym z działów wiedzy o języku"22. Ukonkretniając zaś ten wniosek, badacz dopowiedział: „,...] potencjalne komunikacyjne aspekty doskonalenia języka również zostały unieruchomione wpisaną tu wiedzą z zakresu retoryki czy obowiązujących form wypowiedzi"23.

Takie spostrzeżenia dodatkowo konkretyzuje zawartość przywoływanego tu już kilkakrotnie podręcznika licealnego. Bardzo wyraźnie dokumentuje on powrót do modelu kształcenia językowego sprowadzanego do gromadzenia wiedzy o języku. Ten tradycyjny, by nie rzec: zachowawczy kierunek edukacji lingwistycznej, szczególnie mocno ujawniają różnego rodzaju powtórzenia, repetytoria traktowane jako swoista ,wiedza w pigułce”. Są one bardziej ilustracją encyklopedyzmu niż dążenia do kształtowania uczniowskich kompetencji językowych. Paradoksalnie również w podstawie programowej z 2018 roku znaleźć można podobne deklaracje:

Wzbogacanie wiedzy o języku traktowanym jako rozwijający się system i narzędzie służące poznawaniu świata oraz wartościowaniu ma służyć kształtowaniu u ucznia refleksji porządkującej i pozwalać na świadome uczestnictwo w różnych sytuacjach komunikacyjnych, związanych zarówno $\mathrm{z}$ odbiorem, jak i tworzeniem własnych tekstów. Służy temu również dalsze rozwijanie umiejętności retorycznych, które pozwalają nie tylko na tworzenie własnych wypowiedzi, ale kształtują umiejętności polemiczne oraz pozwalają rozpoznać próby manipulacji i skutecznie się im przeciwstawić.

PP 2018, s. 6-7

Podręcznik ujawnia diametralnie inne cele. Polecenia typu: Wymień i krótko omów funkcje języka w komunikacji. Objaśnij pojęcie znaku. Jakie rodzaje znaków wyróżniamy — nastawione są wyłącznie na sprawdzenie wiedzy. W podobnie odtwórczy sposób bywa traktowana retoryka. Jak dowodził już Jerzy Ziomek, ściśle łączy się ona z komunikacją językową ${ }^{24}$. Tymczasem młody użytkownik podręcznika dowiaduje się z niego, na czym w teorii (nie w praktyce!) polegają perswazja i manipulacja językowa. W szkolnej książce brak bowiem jakichkolwiek tekstów obrazujących te zjawiska, występujące

${ }^{22}$ J. Kaniewski: $W$ poszukiwaniu całości. Koncepcja przedmiotu a przygotowanie nauczycieli. W: Idem: Zadania przedmiotu a formacja kulturowa ucznia nastoletniego. Poznań 2019, s. 27.

${ }^{23}$ Ibidem, przypis 41, s. 27-28. Podkr. - M.K.R.

${ }^{24}$ Zob. J. Ziomek: O wspótczesności retoryki. W: Problemy teorii literatury. Seria 4. Red. H. Markiewicz. Wrocław 1998. Por. M. Rusinek: Między retoryka a retorycznościa. Kraków 2003. 
przecież nader często i w aktualnej — potocznej oraz kulturowej komunika$\mathrm{cji}^{25}$. Licealista poznaje na przykład teorię dotyczącą kompozycji mowy i sposobów argumentacji w nawiązaniu do pojedynku Hektora z Achillesem czy schematów wnioskowania zastosowanych w opisie oblegania starożytnej Troi i Jasnej Góry przez Szwedów. Konia z rzędem temu, kto potrafi przekonująco (zgodnie z zasadami metodyki nauczania) wyjaśnić, jak analiza fragmentów Retoryki Arystotelesa i Iliady Homera ma przygotować ucznia do opracowania mowy mającej zachęcić piętnastolatków do wyjazdu na klasową wycieczkę i dlaczego (na poziomie rozszerzonym?!) mają użyć jednego sylogizmu.

Cel kształcenia językowego odsłania też przygotowane kompendium powtórkowe, w którym jest wyłącznie twarda, definicyjna wiedza. Uczeń znajduje w nim między innymi informacje o tym, czym zajmuje się retoryka, jakie są jej trzy klasyczne cele. Poznaje też zasady układania i wygłaszania mowy (stosowność, poprawność językową, jasność wypowiedzi, ozdobność) oraz etapy jej przygotowania (inventio, dispositio, elocutio, memoria, actio). Przypomina mu się typy mów - począwszy od sądowych (oskarżycielskie i obronne), doradczych (namawiające i odradzające), okolicznościowych, wśród tych ostatnich wymienia się na przykład laudacje. Definicyjnie pisze się o dowodzeniu w tekście retorycznym. Tak samo prezentowane są typy argumentów oraz typy dowodzenia, choć tu zdarzają się przypadkowe przykłady, niepowiązane z jakąkolwiek konkretną mową (dotyczą placu zabaw dla dzieci, badań Biblioteki Narodowej, ale też trójkątów prostokątnych, alergii czy bankowego kredytu...). Jeśli do tego dodamy formuły mówiące, czym jest — zgodnie z teorią — spójność wypowiedzi (także spójność lokalna i globalna), a młody człowiek przebrnie przez informacje o ośmiu wykładnikach koherencji (nadal definicje!), ośmiu wykładnikach spójności tekstu (i tu również definicje), to trudno już chyba będzie mu przyswoić (?) piętnaście określeń środków retorycznych, wśród których uwzględniono między innymi: amplifikację, katachreze, litotę, polisyndeton...

${ }^{25}$ Zagadnienie to świetnie literacko prezentuje między innymi: U. Eco: Temat na pierwsza stronę. Tłum. K. Żaboklicki. Warszawa 2015. Warto też porównać edukacyjnie wątpliwy charakter odległych doświadczeniom uczniów podręcznikowych propozycji z dydaktycznie inspirującymi materiałami przedstawionymi w książce M. Rusinka, A. Załazińskiej: Jak się dogadać, czyli retoryka codzienna. Kraków 2018. Jej autorzy zarówno wykorzystują współczesne, autentyczne przykłady, jak i projektują ćwiczenia obrazujące praktyczną przydatność retoryki, a także objaśniają konsekwencje konkretnych zachowań językowych w sytuacjach bliskich codzienności. Przykłady z otaczającej nas rzeczywistości społeczno-politycznej znaleźć też można w niedawno wydanej publikacji K. Kłosińskiej, M. Ru sinka: Dobra zmiana. Czyli jak się rządzi światem za pomoca stów. Kraków 2019. Choć te ostatnie niekoniecznie muszą być zamieszczane w podręcznikach, to jednak wymieniam i tę publikację, aby przypomnieć o znaczeniu słowa, konsekwencjach jego używania, ale i potrzebie budowania świadomości językowej. A tego także wymaga podstawa programowa z 2018 roku. 
Nie sposób też zrozumieć, jaki dydaktyczny sens ma kolejna, jedynie teoretyczna informacja dotycząca relacji między literaturą a retoryką czy następujące po niej ogólnikowe objaśnienie sztuki prowadzenia sporów i... wyliczenie sześciu chwytów erystycznych. Przykłady wyłącznie encyklopedycznych zapisów zaczerpnąć można z wszystkich rozdziałów i podrozdziałów powtórkowej nauki o języku, co podkreśla się wprost, bez jakichkolwiek odwołań do idei i potrzeby nauki języka.

W podobny sposób w podręczniku wprowadza się również naukę pisania. Podany jest temat, nazwana lub zdefiniowana forma wypowiedzi i już z reguły nie projektuje się w nim koniecznych ćwiczeń z nią związanych. Dotyczy to nawet tak trudnej umiejętności, jak dokonanie i napisanie interpretacji porównawczej, którą to sprawność mają — zgodnie z obowiązującą podstawą programową z 2018 roku — nabyć uczniowie na poziomie rozszerzonym. Tymczasem - co również wiadomo od dawna - w procesie kształcenia nie wystarczy tylko samo zasugerowanie zestawienia tekstów. Trzeba też zaprojektować działania pozwalające nabyć niezbędne w toku przygotowywania tego typu wypowiedzi sprawności, zarówno te dotyczące problematyzowania zestawu, rozpoznawania zasady porównywania podobieństw i różnic, jak i wyłaniania dominant, formułowania hipotez interpretacyjnych. Uczeń musi też mieć świadomość możliwych ujęć kompozycyjnych wypowiedzi porównawczej, zdawać sobie sprawę, jak istotne znaczenie mają jakość opisu analitycznego oraz interpretacja całości. Skoro zaś w podstawie programowej mowa jest o „rozwijaniu świadomości historycznoliterackiej uczniów”, to trzeba też w procesie kształcenia — tym bardziej na poziomie rozszerzonym — wprowadzić elementy wartościowania rozumianego nie tylko jako rozpoznawanie wpisanych w utwory wartości, ale i uwzględnienie kryteriów historycznoliterackich we wnioskowaniu o jakości tekstów. Tego typu umiejętności wymagają zaprojektowania odpowiednich zadań oraz przewidzenia czasu na ich wykonanie i niezwykle ważne korygowanie efektów. Samo sformułowanie tematu interpretacji porównawczej jest zdecydowanie niewystarczające, jeśli chcemy rzeczywiście, a nie tylko formalnie, zrealizować obligatoryjny zapis z ministerialnego dokumentu.

\section{To, co ważne: poza podstawą i podręcznikiem}

Nie przypadkiem zakończyłam fragment dotyczący komunikacji językowej uwagami na temat interpretacji porównawczej. Przykład ten bowiem pozwala zadać pytanie nie tylko o kwestie związane z nauką pisania, ale i o sposób 
urzeczywistniania wymogu wynikającego z podstawy programowej z 2018 roku, a dotyczącego takiego ukierunkowania procesu kształcenia, który „ma służyć osiągnięciu przez ucznia umiejętności świadomego i krytycznego odbioru dzieł literackich, ich interpretacji w różnych kontekstach, rozpoznawania w nich odniesień egzystencjalnych, aksjologicznych i historycznych". Dla nabycia bowiem takich sprawności — zgodnie z zapisem w dokumencie — istotne znaczenie „ma zintegrowanie kształcenia literackiego i językowego” (obydwa cytaty — za: PP 2018, s. 6).

W analizowanej tu przykładowo szkolnej książce prezentuje się jeszcze więcej faktów niż w ministerialnym dokumencie, rzadziej opowiada historie, a niekiedy — jak w przywołanym wcześniej przykładzie — wówczas gdy opowieść o rogach Mojżesza nasuwa się sama, nie wykorzystuje się takiej możliwości... Ten anegdotyczny, zabawny w gruncie rzeczy przypadek pozwala jednak zwrócić uwagę i na kwestię poważniejszą, z którą od dawna mamy kłopot. Szkoła wyłaniająca się z urzędowych dokumentów i wielu — niestety - podręczników nie kreuje opowieści o człowieku — tym historycznym, ale przede wszystkim tym współczesnym; brakuje opowieści, w której odnaleźć mógłby się młody człowiek. W szkicu Dziedzictwo - do przyjęcia czy do odrzucenia pomieszczonym w tomie Problematyka aksjologiczna w literaturze Barbara Kryda cytowała wypowiedzi uczniów z przełomu lat osiemdziesiątych i dziewięćdziesiątych $\mathrm{XX}$ wieku, którzy o czytanych w szkole tekstach mówili: [...] głupi bohaterowie, idiotyczne problemy, niezrozumiaty mistycyzm, ciemny język, chała, denne, nawymyślat, a my musimy analizować ${ }^{26}$. W roku 2006 Bożena Chrząstowska dowodziła:

Dziś już wiemy, że skuteczność procesu trzeba wyprowadzić z myślenia o uczniu i kontekstach kultury, w której on żyje. Uwarunkowania dobrej dydaktyki to: motywowanie działań komunikacyjnych (językowych), motywowanie doświadczeń czytelniczych i audiowizualnych, wiązanie ich z przeżyciami młodych ludzi, poszukiwanie pomostów między światem kultury masowej, w którym żyją, a światem kultury wysokiej, do którego chcemy wychowanków wprowadzić; pobudzanie ich postaw twórczych, samodzielności i inteligencji w rozumieniu i akceptacji tego, co historyczne ${ }^{27}$.

${ }^{26}$ B. Kryda: Dziedzictwo do przyjęcia czy do odrzucenia? O uwarunkowaniach przejmowania wartości w szkolnej lekturze tekstów literackich. W: Problematyka aksjologiczna w literaturze. Studia. Red. S. Sawicki, A. Tyszczyk. Lublin 1992, s. 436.

27 B. Chrząstowska: Przedmiot, podmiot i proces..., s. 167. Cytat pochodzi ze szkicu B. Chrząstowskiej: Jak uczyć historyczności w nowym liceum, którego pierwodruk ukazał się w tomie O historyczności. Red. K. Meller, K. Trybuś. Poznań 2006, s. 43-52. 
Te i inne - sygnalizowane wcześniej — ustalenia dydaktyczne ${ }^{28}$ nie zyskały uznania decydentów i edukacja polonistyczna dalej przebiega w rytmie: im więcej, tym lepiej. Obecnie problem jest chyba jeszcze poważniejszy. W roku 2020 szkolna polonistka domagała się czasu na niespieszne czytanie, którego — wobec przeładowania projektowanej w dokumentach (i podręcznikach dodajmy) edukacji polonistycznej — zwyczajnie brakuje. Nauczycielka zauważyła też:

Wiem, że wprowadzanie w tradycję jest ważne, jednak forma, jaką proponuje nam nowa podstawa dla szkół średnich, przeczy wszelkim potrzebom ucznia. Jedynie strach przed egzaminem może zmusić uczniów do zapoznawania się z treścią lektur. Coraz głośniej powinniśmy mówić o tym, iż istnieją dwie rzeczy: czytanie tekstu literackiego i zapoznawanie się z treścią utworu (błogosławiony Internet!), a szkolna lista lektur raczej zabija czytanie, niż do niego zachęca. Efekt jest taki, że to, co ciekawe w szkole, dzieje się zazwyczaj poza ścisłymi zapisami podstawy programowej, a nie w wyniku jej realizowania ${ }^{29}$.

To, co ważne, rozgrywa się często także poza podręcznikiem. Pozostaje wiara w dydaktyczny rozsądek nauczycielek i nauczycieli.

\section{Bibliografia}

Adamczyk M., Chrząstowska B., Pokrzywniak J.T.: Starożytność-oświecenie. Podręcznik literatury dla klasy pierwszej. Warszawa 1987.

Bortnowski S.: Modele prezentacji malarstwa, grafiki i rysunku w podręcznikach gimnazjalnych. W: Podręcznik jako narzędzie ksztatcenia polonistycznego w gimnazjum. Red. H. Kosętka, Z. Uryga. Kraków 2002, s. 124-132.

Chrząstow ska B.: Cegła. „Polonistyka” 1992, nr 1, s. 53-57.

Chrząstowska B.: Jak uczyć historyczności w nowym liceum. W: O historyczności. Red. K. Me1ler, K. Trybuś. Poznań 2006, s. 43-52.

${ }^{28}$ By nie zaciemniać wywodu, nie wskazałam wielu publikacji dydaktyków, literaturoznawców, językoznawców, pedagogów, psychologów, neurobiologów podobnie traktujących omawiane zagadnienia edukacyjne. Przywołałam — przykładowo — prace Bożeny Chrząstowskiej, Zenona Urygi, Stanisława Bortnowskiego, Barbary Krydy, ponieważ chyba w największym stopniu wpłynęli na moje zapatrywania dydaktyczne, a niektórzy z nich także — jak sądzę — na przekonania sporej grupy innych badaczy polonistyki szkolnej.

${ }_{29}$ I. Starosta: Przyjazna przestrzeń?. „Uczyć Inaczej” 2019/2020, nr 3, s. 5. Podkr. — M.K.R. 
Chrząstows sa B.: Lektura i poetyka. Zarys problematyki ksztaltowania pojęć literackich w szkole podstawowej. Warszawa 1987.

Chrząstowska B.: Przedmiot, podmiot i proces. Szkice z metodyki ksztatcenia polonistycznego. Wybór i oprac. M. Kwiatkowska-Ratajczak, W. Wantuch. Poznań 2009.

Chrząstowska B.: Teoria literatury w szkole. Z badań nad recepcja liryki. Wrocław-Warszawa-Kraków—Gdańsk 1979.

Chrząstowska B., Wójtowicz-Stefańska A.: Ksztattowanie pojęć na lekcjach języka polskiego. W: Innowacje i metody. W kręgu teorii i praktyki. Podręcznik akademicki dydaktyki ksztatcenia polonistycznego. Red. M. Kwiatkowska-Ratajczak. Poznań 2011, s. 267-280.

Eco U.: Temat na pierwsza stronę. Tłum. K. Żaboklicki. Warszawa 2015.

Gajda S.: Język - językoznawstwo - polonistyka. W: Polonistyka w przebudowie. T. 1. Red. M. Czermińska i inni. Kraków 2005, s. 28-38.

Gajda S., Słodzińska A.: Struktura językowa podręcznika. W: Podręczniki literatury w szkole średniej. Wczoraj - dziś - jutro. Red. B. Chrząstow ska. Poznań 1981, s. 117-135.

Gąsiorek K.: Komunikatywność (czytelność) podręczników literatury a język uczniów w szkole średniej. W: Podręczniki literatury w szkole średniej. Wczoraj — dziś - jutro. Red. B. Chrząstowska. Poznań 1981, s. 137-145.

Kaniewski J.: W poszukiwaniu całości. Koncepcja przedmiotu a przygotowanie nauczycieli: W: Id em: Zadania przedmiotu a formacja kulturowa ucznia nastoletniego. Poznań 2019, s. 11-36.

Kłakówna Z.A.: Przymus $i$ wolność. Projektowanie procesu kształcenia kulturowej kompetencji. Kraków 2003.

Kłakówna Z.A.: Sztuka pisania. Ćwiczenia redakcyjne dla klas IV_VI. Metodyczny podręcznik nauczyciela. Warszawa 1993.

Kłakówna Z.A., Steczko I., Wiatr K.: Sztuka pisania. Klasy 1-3 gimnazjum. Ksiązka nauczyciela. Kraków 2003.

Kłosińska K., Rusinek M.: Dobra zmiana. Czyli jak się rządzi światem za pomoca słów. Kraków 2019.

Koc K.: Od gramatyki opisowej do gramatyki komunikacyjnej. „Polonistyka” 2009, nr 4, s. 26-31.

Kołodziej P.: Czas na obraz. Dzieło malarskie jako tekst i kontekst w szkolnym ksztatceniu humanistycznym (1880-1999). Kraków 2013.

Kryda B.: Dziedzictwo do przyjęcia czy do odrzucenia? O uwarunkowaniach przejmowania wartości w szkolnej lekturze tekstów literackich. W: Problematyka aksjologiczna w literaturze. Studia. Red. S. Sawicki, A. Tyszczyk. Lublin 1992, s. 435-460.

Nocoń J.: Lingwodydaktyka na progu XXI wieku. Konteksty — koncepcje - dylematy. Opole 2018.

Rusinek M.: Między retoryka a retorycznościa. Kraków 2003.

Rusinek M., Załazińska A.: Jak się dogadać, czyli retoryka codzienna. Kraków 2018.

Starosta I.: Przyjazna przestrzeń?. „Uczyć Inaczej” 2019/2020, nr 3.

Szczukowski D.: Nauczanie literatury jako wyzwa(la)nie i wyznanie. W: Polonistyka dziś kształcenie dla jutra. T. 1. Red. K. Biedrzycki, W. Bobiński, A. Janus-Sitarz, R. Przybylska. Kraków 2014, s. 409-419.

Uryg a Z.: Kryteria oceny podręczników szkolnych do literatury i historii. W: Prace Komisji do Oceny Podręczników Szkolnych. T. 1. Red. A. Kastory, G. Chomicki. Kraków 2002, s. 13-21.

Uryga Z.: Podręcznik jako narzędzie ksztatcenia literackiego w szkole średniej. W: Podręczniki literatury w szkole średniej. Wczoraj — dziś - jutro. Red. B. Chrząstowska. Poznań 1991, s. $13-34$.

Zgółka T.: Nauczanie o języku (na trzech etapach edukacji szkolnej). „Polonistyka” 1999, nr 7, s. $403-407$.

Ziomek J.: O współczesności retoryki. W: Problemy teorii literatury. Seria 4. Red. H. Markiewicz. Wrocław 1998. 


\section{Źródło internetowe}

Podstawa programowa kształcenia ogólnego dla czteroletniego liceum ogólnokształcącego i pięcioletniego technikum. Załącznik nr 1 do rozporządzenia Ministra Edukacji Narodowej z dnia 30 stycznia 2018. https://archiwum.men.gov.pl/wp-content/uploads/2018/01/zalacznik-nr-1.pdf [data dostępu: 6.11.2018]. 